\title{
Urine xanthine oxidase activity in urinary tract infection
}

\author{
S. GILER, E. F. HENIG, I. URCA, O. SPERLING, AND A. DE VRIES
}

From the Department of Surgery B, the Bacteriological and Chemical Laboratories and the RogoffWellcome Medical Research Institute, Beilinson Medical Center, Tel-Aviv University Medical School, Petah-Tikva, Israel

SUMMARY Xanthine oxidase (XO) activity was found to be negligible in sterile human urines (less $\frac{\omega_{\text {or }}}{\overrightarrow{0}}$ than 480 units, as presently defined, per litre). Significant XO activity was found in all urines con-

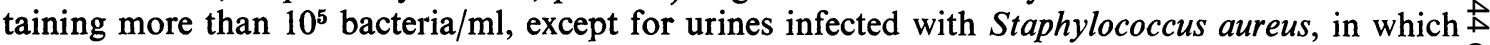
XO activity ranged from 347 to 714 units per litre. Plasma XO is not transferred to the urine, as 을 demonstrated by the negligible XO activity found in sterile urines from patients with raised plasma XO activity. Determination of urinary XO activity is a suitable procedure for the detection of $\underbrace{\frac{3}{2}}$ urinary tract infection.

Measurement in the urine of various enzymes has been proposed as a method for the detection of urinary tract infection (Brenner and Gilbert, 1963; Bank and Bailine, 1965; Mirabile et al., 1966; Montgomerie et al., 1966; Gault et al., 1967; Kallet and Lapco, 1967; Roberts et al., 1967). The diagnostic value of these methods is limited by the potential derivation of the respective urinary enzymatic activities from renal and urinary tract tissues and from blood cells and plasma (Bank and Bailine, 1965; Montgomerie et al., 1966; Gault et al., 1967; Mattenheimer, 1971; Wolf et al., 1973). As shown in the present study, xanthine oxidase (XO) activity is a correlate of urinary tract infection, the enzyme being derived from the pathogenic bacteria exclusively, while the above-mentioned enzyme sources are non-contributory.

\section{Material and methods}

Urine samples were collected from 115 random patients admitted to hospital for a variety of disorders and whose urines had been sent for a variety of reasons for urine culture. In addition, urines were obtained from 12 jaundiced patients with acute hepatitis without urinary tract infection (serum bilirubin ranging from 3.5 to $11.7 \mathrm{mg} / 100 \mathrm{ml}$, SGOT from 253 to $1330 \mathrm{mU} / \mathrm{ml}$ ), and from 18 patients with acute and chronic renal failure, three of the latter with urinary tract infection and 15 without.

Received for publication 21 August 1977
Urine samples were collected in the morning by midstream catch or by a catheter with strict aseptic technique. Gram-stained smears of unspun urine $\frac{\partial}{0}$ were examined in order to assess the presence of bacteria and leucocytes, as a guide to the presence $\stackrel{\square}{\perp}$ of infection. The urines were cultured quantitatively $\vec{P}$ on MacConkey's agar and blood agar plates. $\frac{3}{3}$ Arbitrarily, concentrations of $10^{5}$ and more bacteria per $1 \mathrm{ml}$ of urine were considered as significant for urinary tract infection. Bacteria isolated in cultures were subjected to further identification? procedures. The urines were assayed for XO activity within one hour after collection. In addition, $\mathrm{XO}$ activity was measured in the sera obtained from the $ᄋ$ patients with acute hepatitis, and in renal and liver

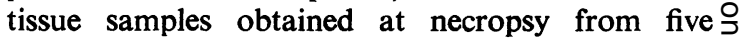
patients with myocardial infarction without urinary tract infection and without jaundice.

XO activity was assayed by incubation of $100 \mu \mathrm{l} N$ of the urine, serum or homogenised tissue samples in a total volume of $250 \mu 1$ of $0.04 \mathrm{M}$ potassium phosphate buffer, pH 8.0, containing $10 \mathrm{nmol} \omega$ of $\left(8-{ }^{14} \mathrm{C}\right)$ hypoxanthine $(25 \mathrm{mCi} / \mathrm{mmol})$. After incubation at $37^{\circ} \mathrm{C}$ for three hours, $100 \mu \mathrm{l}$ of $20 \%$ perchloric acid was added and the tubes were put in $\mathbb{\Phi}$ boiling water for 15 minutes, chilled, and centri- ? fuged for 10 minutes at $3000 \mathrm{rev} / \mathrm{min}$. The free $T$ purine bases in the supernatant were separated in the presence of carriers by thin-layer chromato- $\stackrel{\mathbb{Q}}{\mathcal{D}}$ graphy on Avicel (microcrystalline cellulose), using $\stackrel{\mathbb{\perp}}{\stackrel{\perp}{2}}$ n-butanol:methanol:water: $\mathrm{NH}_{4} \mathrm{OH} 25 \%(60: 20: 20: 0$ $1 \mathrm{v} / \mathrm{v})$ as solvent. The purines were located on the chromatogram under ultraviolet light, the urico 
acid spot was scraped off and suspended in Bray's solution, and the radioactivity was counted in a Packard Tricarb Liquid Scintillation Counter Model 3380. The activity of the enzyme is expressed in units/litre (U/l), one unit being the amount of enzyme catalysing the oxidation of $1 \mathrm{nmol}$ of hypoxanthine to uric acid in one hour at $37^{\circ} \mathrm{C}$. For evaluation of liver and renal tissue XO activity, $500 \mathrm{mg}$ of tissue were homogenised, within four hours after death, in $1 \mathrm{ml}$ of $0.04 \mathrm{M}$ potassium phosphate buffer, pH $8.0 ; 100 \mu$ l of tissue homogenates was assayed.

\section{Results}

The XO activity in the normal and the infected urines is presented in Table 1 . Out of the 115 random urines examined for XO activity, 40 were found to contain more than $10^{5}$ bacteria per $\mathrm{ml}$. In all these 40 infected urines, the level of XO activity was above $1000 \mathrm{U} / \mathrm{l}$, except in four urines harbouring Staph. aureus, in which XO activity ranged from 347 to $714 \mathrm{U} / 1$. In the other 75 urines, containing less than $10^{5}$ bacteria per ml, the enzyme level was lower than 480 U/1. Significant XO activity was not found in any of many experiments in which urine specimens containing $10^{2}$ and $10^{3}$ bacteria per $\mathrm{ml}$ were studied. However, in urine specimens containing $10^{4}$ to $10^{5}$ bacteria per $\mathrm{ml}$, XO activity ranged from 90 to $480 \mathrm{U} / \mathrm{l}$, the lower values found in such urines contaminated with Staph. aureus, Proteus mirabilis, or Klebsiella, the higher values in such urines contaminated with Pseudomonas aeruginosa, Enterobacter aerogenes, or Escherichia coli.

It can be seen from the table that in the urines containing pathogenic bacteria, the highest XO activity was found in urines containing $E$. coli, and the lowest activity in urines containing $P$. mirabilis.

Urine specimens containing mixed cultures of $E$. coli and $P$. mirabilis, and of Enterobacter aerogenes and $P$. mirabilis, were also studied. In all these urines XO activity could be related to the total concentration of bacteria.

The urines of 12 patients with acute hepatitis, who had no urinary infection, had a mean XO activity of $41 \mathrm{U} / \mathrm{l}$ (range $0-130 \mathrm{U} / \mathrm{l}$ ); the XO activity in their sera was raised, ranging from 1410 to 16030 $\mathrm{U} / \mathrm{l}$, as compared to the normal range of serum XO activity (0-395 U/l) found in our laboratory (Giler et al., 1975).

In the urines of the 15 patients with renal insufficiency ( 9 chronic and 6 acute) and negative urine culture, mean XO activity was $43 \mathrm{U} / 1$ (range 0-120 U/1), but in the urines of the three
Table 1 Xanthine oxidase activity in sterile and infected urines

\begin{tabular}{|c|c|c|}
\hline \multirow[t]{2}{*}{ Urine sample } & \multicolumn{2}{|c|}{$X O(U / l)$} \\
\hline & Mean & Range \\
\hline $\begin{array}{l}\text { Sterile (75) } \\
\text { Infected (40) }\end{array}$ & 37 & $0-480$ \\
\hline $\begin{array}{l}\text { Escherichia coli }(17) \\
\text { Enterobacter aerogenes (4) } \\
\text { Pseudomonas aeruginosa (3) } \\
\text { Klebsiella (3) } \\
\text { Proteus mirabilis (9) } \\
\text { Staphylococcus aureus (4) }\end{array}$ & $\begin{array}{r}12958 \\
5415 \\
6289 \\
2721 \\
1651 \\
483\end{array}$ & 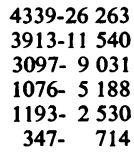 \\
\hline
\end{tabular}

Numbers in paratheses indicate number of patients examined.

Table 2 Xanthine oxidase activity in human tissues

\begin{tabular}{lcc}
\hline Tissue & \multicolumn{2}{l}{ XO (U/mg tissue) } \\
\cline { 2 - 3 } & Mean & Range \\
\hline Kidney (5) & 1.6 & $0-2.4$ \\
Liver (3) & 793.9 & $692 \cdot 8-893.4$ \\
\hline
\end{tabular}

Numbers in parentheses indicate number of necropsies.

patients with chronic renal failure and positive urine cultures XO activity was raised: 1590,1450 , and $1860 \mathrm{U} / \mathrm{l}$, respectively. Renal tissue homogenates (see Table 2) contained only traces of XO activity, whereas the liver homogenates contained high XO activity.

\section{Discussion}

The enzymes which have been most extensively studied in the urine as markers for urinary tract infection are lactic dehydrogenase, glutamic oxaloacetic transaminase, alkaline phosphatase, $\beta$ glucuronidase, and catalase (Brenner and Gilbert, 1963; Bank and Bailine, 1965; Gault et al., 1967; Mirabile et al., 1966; Montgomerie et al., 1966; Kallet and Lapco, 1967; Roberts et al., 1967; Woodruff et al., 1972). In view of the contribution of tissue-derived enzymes to the urinary enzymatic activities, the use of an urinary enzymic marker for the detection of urinary tract infection would require that urinary enzymatic activity derived from the pathogenic bacteria only, with exclusion of tissue sources. For this reason we have chosen the enzyme XO. This enzyme is confined in man mainly to the liver (Morgan, 1926; Ramboer, 1969); a significant but lower activity has been found also in jejunal mucosa and colostrum (Watts et al., 1964; Ramboer, 1969); on the other hand, the kidney, prostate, and blood elements, as well as normal serum, are virtually devoid of XO activity (Al- 
Khalidi and Chaglassian, 1965; Ramboer, 1969; Shamma'a et al., 1973; Giler et al., 1975). Indeed, in the present study, urinary XO activity was shown to relate specifically to pathogenic urinary bacteria, increased activity being present only in the urines containing bacteria in amounts greater than $10^{5}$ per $\mathrm{ml}$.

It is noteworthy that urine XO activity was not increased in patients with acute hepatitis who all had high serum XO activities, conforming to previously reported results (Shamma'a et al., 1973; Giler et al., 1975), indicating that plasma XO is not transferred to the urine, probably due to its high molecular weight. Furthermore, it was shown in the present study that, under the methodological conditions applied, renal tissue is virtually devoid of XO activity. In the presently studied patients with renal disease, XO activity appeared in the urine only when urinary tract infection was present. Moreover, even in the patients with renal tubular necrosis, in whom renal tissue-derived enzyme activity, such as lactic dehydrogenase, alkaline phosphatase, leucine aminopeptidase, and $\beta$-glucuronidase is known to appear in the urine (Wolf et al., 1973), the urine XO activity was not increased. Thus, urinary XO activity seems to constitute a satisfactory indication of the presence of urinary tract infection. Preliminary studies with the pathogenic bacteria isolated from the infected urines have shown that cultures of these bacteria displayed XO activity. Studies are in progress to characterise the bacterial enzymes involved in the degradation of hypoxanthine, and to automate the technique of urinary XO estimation.

\section{References}

Al-Khalidi, U. A. S., and Chaglassian, T. H. (1965). The species distribution of xanthine oxidase. Biochemical Journal, 97, 318-320.

Bank, N., and Bailine, S. L. (1965). Urinary beta-glucuronidase activity in patients with urinary tract infection. New England Journal of Medicine, 272, 70-75.

Brenner, B. M., and Gilbert, V. E. (1963). Elevated levels of lactic dehydrogenase, glutamic-oxalacetic transaminase, and catalase in infected urine. American Journal of the Medical Sciences, 245, 31-42.
Giler, Sh., Sperling, O., Brosh, S., Urca, I., and으 de Vries, A. (1975). Serum xanthine oxidase in jaundice. Clinica Chimica Acta, 63, 37-40.

Gault, M. H., Oliver, J. A., Lang, C., Asghar, M. I.,을 and Levy, S. W. (1967). Urinary enzymes in benigno and malignant urinary tract disorders: alkaline $\bar{\omega}$ phosphatase and lactic acid dehydrogenase. British $\overparen{\mathbb{D}}$ Journal of Urology, 39, 296-306.

Kallet, H. A., and Lapco, L. (1967). Urine beta glucu-œึ ronidase activity in urinary tract disease. Journal of $\vec{O}$ Urology, 97, 352-356.

Mattenheimer, H. (1971). Enzymes in the urine. Medical $\overrightarrow{\vec{\omega}}$ Clinics of North America, 55, 1493-1508.

Mirabile, C. S., Bowers, G. N., Jr., and Berlin, B. B 횽 (1966). Urinary lactic dehydrogenase: A report based $\omega$ on 250 hospitalized patients. Journal of Urology, $\stackrel{\vec{c}}{\mathrm{C}}$ 95, 79-82.

Montgomerie, J. Z., Kalmanson, G. M., and Guze, L. B. (1966). The use of the catalase test to detect significant

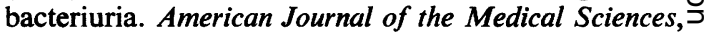
251, 184-187.

Morgan, E. J. (1926). The distribution of xanthine oxidase. I. Biochemical Journal, 20, 1282-1291.

Ramboer, C. R. H. (1969). A sensitive and nonradioactive $\overrightarrow{0}$ assay for serum and tissue xanthine oxidase. Journal of $\infty_{\infty}^{\infty}$ Laboratory and Clinical Medicine, 74, 828-835.

Roberts, A. P., Frampton, J., Karim, S. M. M., and Beard, R. W. (1967). Estimation of $\beta$-glucuronidase activity in urinary-tract infection. New England $\bar{O}$ Journal of Medicine, 276, 1468-1470.

Shamma'a, M. H., Nasrallah, S. M., and Al-Khalidi, $\stackrel{\mathbb{Q}}{\mathbb{Q}}$ U. A. S. (1973). Serum xanthine oxidase, an experience with 2000 patients. American Journal of Digestive Diseases, 18, 15-22.

Watts, R. W. E., Engelman, K., Klinenberg, J. R., Seegmiller, J. E., and Sjoerdsma, A. (1964). Enzyme? defect in a case of xanthinuria. Nature, 201, 395-396.

Woodruff, M. W., Covert, S. V., Litinsky, S. M., and? Vanneman, W. M. (1972). Quantitative urinary catalase measurement: a new mass screening technique for bacteriological and cellular urine abnormality. Journal of Urology, 107, 117-119.

Wolf, P. L., Williams, D., and Von der Muehll, E. (1973).윽 Practical Clinical Enzymology: Techniques and Interpretations, and Biochemical Profiling, pp. 323-341.음 Wiley, New York.

Requests for reprints to: $\mathrm{Dr}$ S. Giler, Rogoff- $N$ Wellcome Medical Research Institute, Beilinson Medical N Center, Petah-Tikva, Israel. 